\title{
Towards an Improved Conceptualization of Riparian Zones in Boreal Forest Headwaters
}

\author{
José L. J. Ledesma, ${ }^{1 *}$ Martyn N. Futter, ${ }^{1}$ M. Blackburn, ${ }^{2}$ Fredrik Lidman, ${ }^{2}$ \\ Thomas Grabs, ${ }^{3}$ Ryan A. Sponseller, ${ }^{4}$ Hjalmar Laudon, ${ }^{2}$ Kevin H. Bishop, ${ }^{1,3}$ \\ and Stephan J. Köhler ${ }^{1}$
}

\begin{abstract}
${ }^{1}$ Department of Aquatic Sciences and Assessment, Swedish University of Agricultural Sciences (SLU), P.O. Box 7050, 75007 Uppsala, Sweden; ${ }^{2}$ Department of Forest Ecology and Management, Swedish University of Agricultural Sciences (SLU), Umeå, Sweden; ${ }^{3}$ Department of Earth Sciences, Uppsala University, Uppsala, Sweden; ${ }^{4}$ Department of Ecology and Environmental Sciences, Umea University, Umea, Sweden
\end{abstract}

\begin{abstract}
The boreal ecoregion supports about one-third of the world's forest. Over $90 \%$ of boreal forest streams are found in headwaters, where terrestrial-aquatic interfaces are dominated by organic matter $(\mathrm{OM})$ rich riparian zones (RZs). Because these transition zones are key features controlling catchment biogeochemistry, appropriate RZ conceptualizations are needed to sustainably manage surface water quality in the face of a changing climate and increased demands for forest biomass. Here we present a simple, yet comprehensive, conceptualization of RZ function based on hydrological connectivity, biogeochemical processes, and spatial heterogeneity. We consider four dimensions of hydrological connectivity: (1) laterally along hillslopes, (2) longitudinally along the stream, (3) vertically down the riparian profile, and (4) temporally through eventbased and seasonal changes in hydrology. Of particular importance is the vertical dimension, characterized by a 'Dominant Source Layer' that has the highest contribution to solute and water fluxes to
\end{abstract}

streams. In addition to serving as the primary source of OM to boreal streams, RZs shape water chemistry through two sets of OM-dependent biogeochemical processes: (1) transport and retention of OM-associated material and (2) redox-mediated transformations controlled by RZ water residence time and availability of labile OM. These processes can lead to both retention and release of pollutants. Variations in width, hydrological connectivity, and OM storage drive spatial heterogeneity in RZ biogeochemical function. This conceptualization provides a useful theoretical framework for environmental scientists and ecologically sustainable and economically effective forest management in the boreal region and elsewhere, where forest headwaters are dominated by low-gradient, OM-rich RZs.

Key words: terrestrial-aquatic interface; riparian buffer; soil organic matter; redox; forest management; water quality; catchment biogeochemistry; hydrological connectivity; catchment heterogeneity.
Received 4 August 2016; accepted 2 April 2017; published online 21 April 2017

Author contributions JLJL proposed the structure of the paper and wrote it in collaboration with MNF, MB, FL, TG, RAS, HJ, KHB, and SJK, who contributed to the writing and conceptualization.

*Corresponding author; e-mail: jose.ledesma@slu.se

\section{INTRODUCTION}

Surface water quality is to a large degree determined by substances mobilized from the surrounding catchment soils. Thus, the area of interaction between soils and waters is a primary 
focus for both research and management. In this context, terrestrial-aquatic interfaces have long been recognized as hot spots for biogeochemical reactions, which may be activated during hot moments connected to hydrological events (McClain and others 2003; Vidon and others 2010).

In boreal forest headwaters, the link between terrestrial and aquatic environments is dominated by organic matter (OM)-rich riparian zones (RZs). The boreal ecozone covers more than ten million square kilometers of the northern circumpolar region including Fennoscandia and large parts of North America and Russia (Apps and others 1993; Magnani and others 2007). RZs along small running waters are an important part of the overall landscape in the boreal ecozone as headwater streams make as much as $90 \%$ of the total stream length (Bishop and others 2008). This is a higher proportion than the reported value for other ecozones (Horton 1945; Raymond and others 2013), although headwater stream lengths might have been underestimated in the overall fluvial network in those systems (Benstead and Leigh 2012). Functioning of these sensitive and biogeochemically active interface zones can be altered by natural disturbance (for example, fire) (Adams 2013) or human activity (for example, forest harvesting and resource extraction) (Kreutzweiser and others 2008; Gauthier and others 2015), which occur throughout the boreal ecozone.

The accumulation of high levels of OM at the land-water interface is a distinguishing feature of RZs along many small boreal forest streams, in contrast to RZs in other forest biomes (for example, Mediterranean catchments) (Lupon and others 2016). This OM accrual is the result of paludification following glacial retreat in northern latitudes, that is, the formation of peatlands resulting from the long-term interaction between landscape, climate, biota, and disturbances (Lavoie and others 2005). Topography is the key landscape factor that shaped paludification by controlling the development of drainage structure, hydrological connectivity, and water accumulation (Jencso and others 2009). Climate factors playing a role during paludification include precipitation, which influences groundwater levels and flows and thereby the redox state and potential for OM mobilization, and temperature, which regulates rates of microbial and plant activity which in turn determines the production and decomposition of OM (DeLuca and Boisvenue 2012). Temperature and plant growth also influence rates of evapotranspiration and the overall water balance. Commonly located in lowlying flat areas, boreal RZs usually have shallow groundwater tables that can cause hypoxic conditions, which together with low temperature for much of the year result in slow decomposition and subsequent accumulation of OM (Luke and others 2007). That is, primary production rates exceed mineralization rates locally, leading to the characteristic OM accumulation, which in turn can increase the soil water holding capacity contributing to more hypoxia. Apart from natural processes, human-related disturbances may significantly alter terrestrial-aquatic connectivity and rates of $\mathrm{OM}$ accumulation. For example, ditching was an important disturbance in many headwater streams in Fennoscandia during the early twentieth century (Åström and others 2001). This practice was common to improve drainage and forest productivity.

From both scientific and management perspectives, physical, biogeochemical, hydrological, and ecological aspects of RZ function in the boreal forest and elsewhere are all interrelated. For example, ecologists often focus on the biological communities, which are often more diverse in RZs than in upslope areas (Gregory and others 1991; Jansson and others 2007; Onaindia and others 2013). On the other hand, hydrologists may focus on the relative contribution of riparian and upslope areas to runoff, which is usually disproportionally larger in the RZ that is hydrologically connected to the stream (Rodhe 1989; McGlynn and McDonnell 2003). Ecology and hydrology are related because the high water inputs to the RZ may bring nutrients from upslope areas that are, in part, responsible for high levels of biological diversity (Kuglerová and others 2014b). Hydrology becomes the key factor connecting terrestrial and aquatic environments (Vidon and Hill 2004), which can explain how mobilization of relatively old water during runoff events creates a broad spectrum of flow-concentration relationships across RZs (Bishop and others 2004). From a biogeochemical perspective, the high OM content of soils found in most RZs (Naiman and Décamps 1997), and especially in those located in boreal forests, exerts widespread influences over the processing of substances during their hydrological transport to the aquatic environment. Due to its chemical exchange capacity and potential to support microbial activity, OM interacts and affects biogeochemically almost any chemical element or compound (Schlesinger 1997; Vestin and others 2008; Herndon and others 2015).

Broadly, the RZ can be defined as the zone of direct interaction between terrestrial and aquatic environments (Swanson 1981; Naiman and Décamps 1997). From a management perspective, 
boreal RZs have often been conceptualized as a fixed width buffer along a water course (Gundersen and others 2010). Although such an approach is easy to implement and monitor, it fails to adequately capture the spatial and temporal heterogeneity in key functional attributes. Recent work has suggested that there is a need to refine the definition of boreal forest RZ buffer strips (Laudon and others 2016). Specifically, these authors argue that buffer zones should be defined on the basis of landscape hydrology and aimed at identifying and protecting sensitive areas along streams from the potential negative consequences of forestry. Despite this conceptual advance, current forest management approaches still fail to take sufficient account of hydrological connectivity, OM-driven biogeochemical functioning, and spatial heterogeneity. These shortcomings in the conceptualization of RZ functioning increase the likelihood of undesirable outcomes for water quality in the boreal forest due to the interactions of a changing climate and increased demands for forest biomass (Oni and others 2015). Previously, RZ structure and function have been characterized from a longitudinal perspective based on erosional, transitional, and depositional properties (Tabacchi and others 1998). However, such conceptualization lacks a vertical connectivity perspective and may not be appropriate to characterize RZs in low-gradient OM-rich boreal headwaters where gravitydriven erosional processes are often of minor importance.

Here we present a simple, yet comprehensive, conceptualization of boreal RZ hydrological connectivity, OM-driven biogeochemical functions, and spatial heterogeneity as they apply to a wide range of chemical elements and compounds. We focus on RZ control of boreal surface water quality and base our conceptualization on integrating basic biogeochemical and hydrological theory with past and ongoing research in the Swedish boreal forest. Other geographical areas, including elsewhere in the boreal ecoregion and catchments with peat or till soils, are also considered as several RZ features and functions are general and widespread. The spatial scale we focus on includes small to medium size catchments (that is, headwaters from a few hectares to a few square kilometers). At this scale, the RZ influence on stream chemistry is larger than at downstream locations where riparian signals are attenuated by in-stream processes, mixing of upstream waters, or through increased influence of non-riparian sources and processing (for example, deep groundwater or lake) (Hagedorn and others 2000; Bernal and others 2012; Peralta-Tapia and others 2015). Our conceptualization is timely as it moves beyond the hot spot and hot moment concepts introduced by McClain and others (2003), a need that has been recently highlighted by Bernhardt and others (2017).

We start by defining the RZ in the boreal forest so to establish the context. We then conceptualize RZ hydrological connectivity with special focus on the vertical dimension. We describe the role of the RZ as a main source of OM into streams and the biogeochemical functions of retention and redox-mediated transformation driven by the OM in the RZ. Additionally, we discuss the role of timescales and hydrology in relation to riparian biogeochemical functions. Finally, we characterize RZ spatial heterogeneity and briefly review and suggest methods for mapping hydrological connectivity and RZ areas. The ultimate aim of this paper is to propose a conceptualization that can provide a useful theoretical framework for environmental scientists, land managers, and foresters. Thus, we conclude by discussing potential implications for riparian upscaling and land management.

\section{Defining Riparian Zone in the Boreal FOREST}

Our main criterion to define boreal RZs relies on the marked soil transition in boreal catchments from mineral soils in upslope areas (generally podzols) to organic soils in the near-stream zone (generally histosols) (Chesworth 2008). RZs are hence defined as the area between the edge of the stream and the characteristic transition between organic and mineral soils. This definition assigns primary importance to OM content as we assume boreal headwater RZs are typified by organic soils, comparable to small wetlands within forest catchments. This definition based on soil characteristics also has topographical and biological dimensions. The aforementioned soil transition is usually accompanied by an increasing terrain slope and by vegetation changes from mosses (Sphagnum spp.), Norway spruce (Picea abies), and occasional deciduous trees (Betula spp., Alnus spp.) present within organic RZs to vaccinium shrubs (Vaccinium spp.) and Scots pine (Pinus sylvestris) dominating in drier, mineral-soil dominated upslope areas (Grabs and others 2012).

Certainly, soils in the near-stream area can also be inorganic in boreal landscapes, especially in well-drained soils dominated by coarse and deep sediments (Grabs and others 2012). However, our focus is appropriate in the context presented here 
as organic RZs dominate in headwaters underlain by till, which is the predominant soil type in the recently glaciated landscape of the boreal region (Chesworth 2008).

Moreover, we primarily focus on RZs that are hydrologically connected to streams and contribute the most to surface water biogeochemistry. Our conceptualization is suitable for RZs adjacent to streams in landscapes that may or may have not been affected by ditching or channel straightening in the past. In summary, the systems we focus on are organic RZs on forest till soils that are hydrologically connected to streams, widespread in boreal regions but also found in other areas worldwide (for example, Dick and others 2015). Hereafter, unless otherwise specified, the RZ acronym will refer to this type of systems.

\section{Conceptualizing Riparian Zone Hydrological ConNeCTIVITY}

Hydrological connectivity is a key aspect to consider when assessing RZ biogeochemical functioning and potential impacts on surface water quality (Laudon and others 2011; Blume and van Meerveld 2015). Following Ward (1989), we propose four dimensions of hydrological connectivity: (1) laterally along the hillslope, (2) longitudinally along the stream, (3) vertically down the riparian profile, and (4) temporally through event-based and seasonal changes in hydrology that expand or contract the spatial dimensions (Figure 1A). The longitudinal and lateral dimensions have recently received attention because wet areas which expand and contract synchronously with high and low base flow conditions (Ågren and others 2015) can be mapped using catchment surface topography (Murphy and others 2008; Blume and van Meerveld 2015).

Vertical heterogeneities in RZ down the profile are sometimes acknowledged (Lyon and others 2011), but the current conceptualization of hydrological connectivity between streams and RZs in the vertical dimension remains vague. RZs are often characterized by an exponential increase in field capacity, permeability, and hydraulic conductivity toward the soil surface (Nyberg and others 2001). As a consequence, the lateral movement of water to the stream increases dramatically as groundwater table rises and enters highly conductive layers during episodes (that is, precipitation and snowmelt events). This is a common phenomenon in boreal catchments (Moldan and
Wright 1998; Bishop and others 2011), and in till soils worldwide (McDonnell and others 1998; McGlynn and McDonnell 2003; Seibert and others 2003), which leads to a characteristic relationship between stream flow and groundwater tables in the RZ (Figure 2A). Therefore, the overall lateral flux is a function of both the hydraulic conductivity and the fraction of time that groundwater exceeds a certain depth (Figure 2B). For example, there is only a minor lateral flux from deeper permanently wet sections of the soil profile as the hydraulic conductivity is very low. Similarly, areas of very high hydraulic conductivity very near to the soil surface might not be activated even during extreme high flow events and thus do not contribute to the overall lateral flux. The majority of lateral fluxes to the stream thus originates from a relatively shallow depth and converges to a narrow layer in the riparian profile, as suggested by Schiff and others (1998). We propose to denominate this small region as the 'Dominant Source Layer,' a relatively narrow depth range within the RZ with the highest contribution to solute and water fluxes to the stream (Ledesma and others 2015; Blackburn and others 2017). In other words, the mobilization of solutes to streams is effectively limited to only a small fraction of the total RZ volume (Figure 2B). The Dominant Source Layer thickness was quantified in 11 riparian profiles in till soils within a boreal catchment, spanning from only about $13 \mathrm{~cm}$ to about $57 \mathrm{~cm}$, or on average $32 \pm 14 \mathrm{~cm}$ (Ledesma and others 2015). Narrower Dominant Source Layers were found in RZs with very shallow and relatively stable water table positions that concentrated lateral fluxes to the upper soil layers.

This flowpath structure has important biogeochemical implications as stream chemistry will be mostly determined by processes occurring in the Dominant Source Layer. Severe disturbance to forest stands (for example, final felling, windfall via storms, or insect-induced mortality) leading to decreased interception and evapotranspiration will tend to raise groundwater levels. Future climate change with expected increased precipitation will tend to have the same impact, even taking into account the effect of higher temperatures that will increase evapotranspiration (Oni and others 2015). A potential shift of the Dominant Source Layer to upper riparian soil horizons would imply that previously hydrologically disconnected strata within the RZ volume may start reacting with or mobilizing stored substances. These changes could either decrease or increase the capacity of RZs to buffer surface water pollution. 


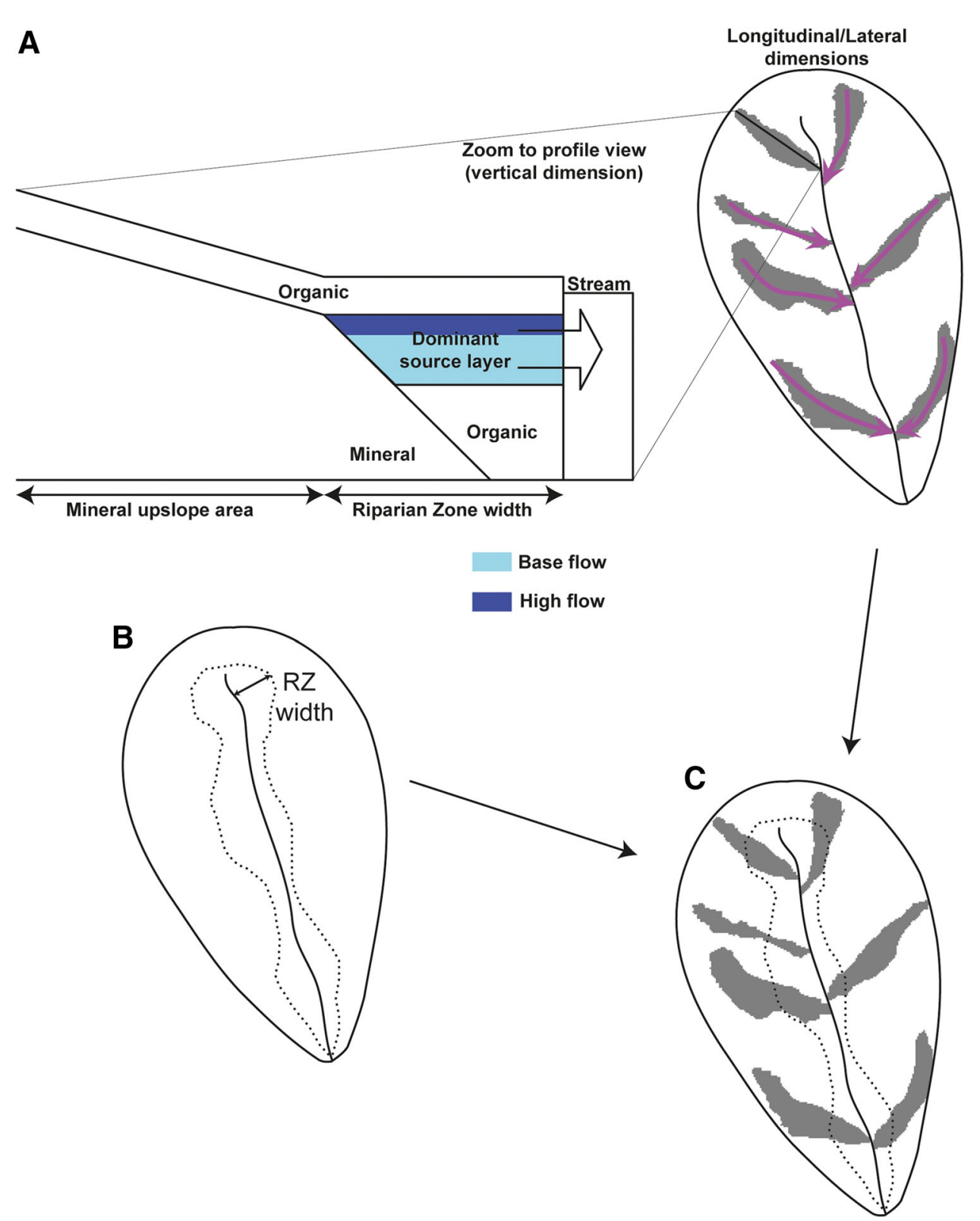

Figure 1. A Pattern of hydrological connectivity in a hypothetical headwater catchment including examples of important local drainage areas in the hillslope that represent lateral and longitudinal dimensions that connect to specific reach segments. The vertical dimension down the riparian profile is characterized by a narrow Dominant Source Layer that is responsible of most of the lateral water flux to the stream. B Conceptualization of the heterogeneous spatial distribution of riparian zone (RZ) widths along the stream based on the characteristic transition between organic and mineral soils in boreal forest hillslopes. C Overlapping between the most important hydrologically connected areas and the RZ widths, which are wider in wetter areas.

\section{Conceptualizing Riparian Zone Biogeochemical Functions}

Chemical elements in soils, including boreal forest soils, originate from four primary sources: (1) biological fixation from atmosphere, (2) atmospheric deposition, (3) weathering from minerals, and (4) point sources from human activities (Table 1). Biological fixation from the atmosphere refers mainly to $C$ (that is, photosynthesis) but can also include nitrogen $(\mathrm{N})$ fixation (for example, riparian alder swamps). Due to the low RZ proportion in relation to the total catchment area (for example, ca. 10\%, McGlynn and Seibert 2003), elements from the atmosphere are deposited mostly in upslope soils, where they can later be leached to the RZ. This implies that most of the water passing through the RZ derives from the upslope areas in the rest of the catchment. Weathering is quantitatively more important in upslope soils as a result of, again, the larger upslope proportion and the mineral-like soils here. Nevertheless, weathering in the RZ can still be quantitatively important, especially if the mineral fraction here has a fine texture that allows for a large mineral surface area and consequent higher rates of element release (Erlandsson and others 2016). Biological nutrients such as C, N, phosphorous $(\mathrm{P})$, and, in general, other elements 


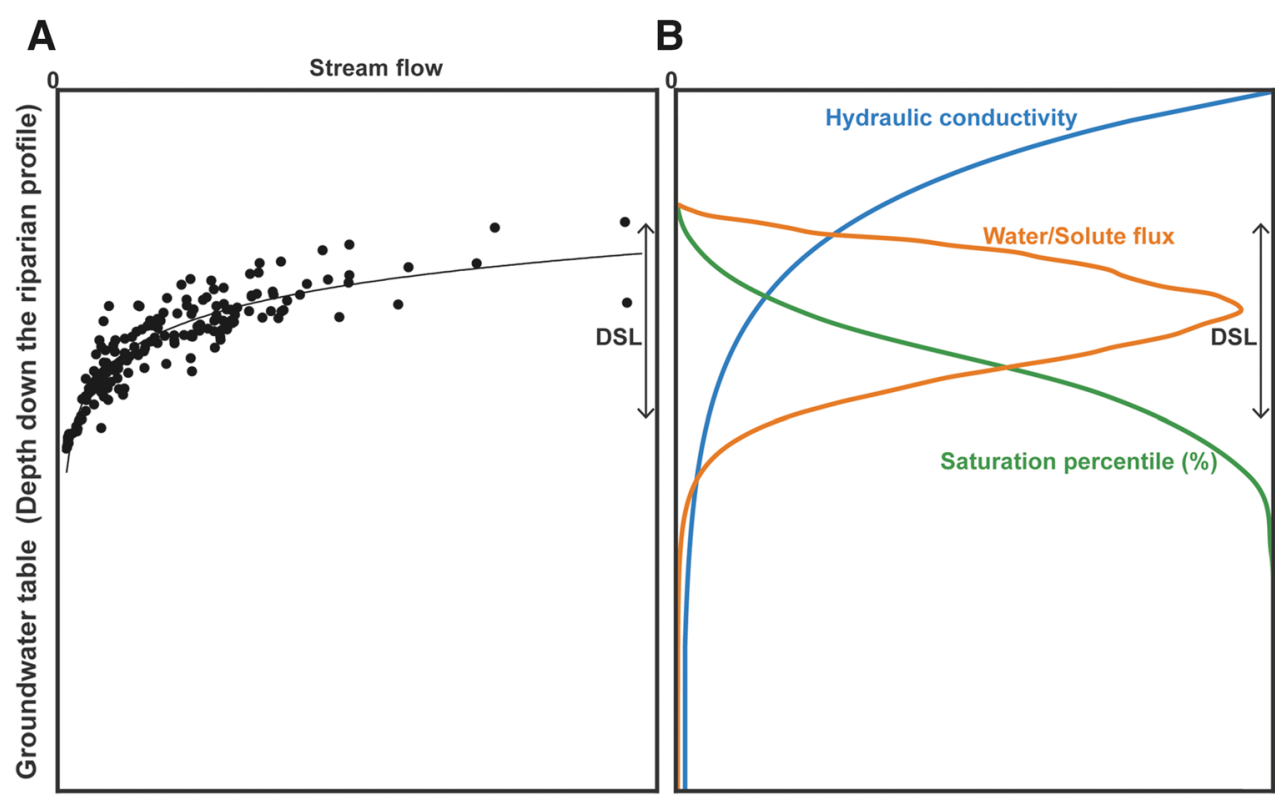

Figure 2. A Characteristic relationship between stream flow and groundwater tables in boreal riparian zone soils exemplified with actual daily data from a riparian profile within a Swedish headwater catchment. Following Darcy's law, the amount of water moving laterally through the riparian profile is equivalent to the stream flow. This means that for any given stream discharge, lateral flows at any given soil layer are proportional to the stream discharge-groundwater table curve and thus can be calculated and can be used to estimate the Dominant Source Layer (DSL). B Conceptualization of the vertical dimension down the riparian profile in hydrological connectivity including the DSL. Saturation percentile refers to the percentage of time that a specific depth is below the groundwater table during a hypothetical hydrological year.

that interact with the OM pool, will be subject to important internal cycling, whether they arrive in the RZ via biological fixation, atmospheric deposition, or upslope inputs.

In addition to providing most stream OM (Dosskey and Bertsch 1994), RZs can either retain or transform chemical elements and compounds derived from upslope inputs, in situ deposition, or in situ weathering on their way to the stream (Figure 3). Retention via interaction with $\mathrm{OM}$ and transformation via redox reactions are fundamental RZ biogeochemical functions, specific to the particular chemical element or compound. We will now describe these two biogeochemical functions providing specific examples, as well as summarize evidence of the importance of RZs for OM catchment exports. $\mathrm{C}$ represents the largest fraction of the OM (Mattsson and others 2009) and will be the primary focus. We will also interpret the role of timescales and hydrology.

\section{Riparian Zones as Sources of Stream Organic Matter}

A direct consequence of the RZ potential to accumulate OM is that they act as the main source of organic compounds to the stream (Figure 3A). For example, RZ width is correlated with lateral organic C fluxes (Ledesma and others 2015) and likely also with the export of other substances interacting with OM. Leaf litter leachate, plant root exudates, and soil microflora degradation products are the secondary sources sustaining the OM pool in the RZ. The quantitative importance of these $\mathrm{C}$ fluxes varies over time and is primarily driven by drying/ wetting and thawing/freezing cycles (DeLuca and Boisvenue 2012). Direct litterfall to boreal headwater streams is often small relative to temperate zone counterparts (Lidman and others 2017) and likely is less important to the allochthonous OM load than inputs delivered via lateral hydrological transfer through organic-rich RZ soils. At the same time, in-stream processing of bulk organic $C$ is potentially a minor loss term in boreal headwaters, owing to short water residence times (Winterdahl and others 2016), particularly during high flow periods (Raymond and others 2016; but see Rasilo and others 2017).

Multiple lines of evidence support the apparent disconnection between upslope and $\mathrm{RZ}$ in the transfer of $\mathrm{C}$ to streams (Löfgren and Zetterberg 2011). First, riparian and upslope $C$ differ in both 
Table 1. Primary Sources of Chemical Elements and Compounds in Catchments, Retention Capacity of the Riparian Zone via Organic Matter (OM) or Whether the Element can be Part of the OM Itself, and Examples of Main Redox Transformation Processes with Environmental Significance

\begin{tabular}{|c|c|c|c|}
\hline Chemical & Source in catchments & $\begin{array}{l}\text { Retention capacity } \\
\text { of the riparian zone }\end{array}$ & Redox transformations \\
\hline $\mathrm{C}$ & Biological fixation & Part of OM & $\begin{array}{l}\text { Methane }\left(\mathrm{CH}_{4}\right) \text { formation } \\
\mathrm{CO}_{2} \text { formation }\end{array}$ \\
\hline $\mathrm{N}$ & $\begin{array}{l}\text { Atmospheric deposition } \\
\text { Biological fixation } \\
\text { Point sources }\end{array}$ & Part of OM & $\begin{array}{l}\text { Nitrate }\left(\mathrm{NO}_{3}{ }^{-}\right) \text {removal } \\
\text { Ammonium }\left(\mathrm{NH}_{4}{ }^{+}\right) \text {formation }\end{array}$ \\
\hline $\mathrm{P}$ & $\begin{array}{l}\text { Weathering } \\
\text { Point sources }\end{array}$ & $\begin{array}{l}\text { Part of OM } \\
\text { Medium (inorganic) }\end{array}$ & \\
\hline$S$ & $\begin{array}{l}\text { Atmospheric deposition } \\
\text { Weathering }\end{array}$ & $\begin{array}{l}\text { Part of OM } \\
\text { Medium (inorganic) }\end{array}$ & Sulfate $\left(\mathrm{SO}_{4}{ }^{2-}\right)$ formation \\
\hline $\mathrm{Mg}, \mathrm{Ca}, \mathrm{Na}$ & $\begin{array}{l}\text { Weathering } \\
\text { Atmospheric deposition }\end{array}$ & Low & \\
\hline K & $\begin{array}{l}\text { Weathering } \\
\text { Atmospheric deposition }\end{array}$ & $\begin{array}{l}\text { Low } \\
\text { interaction with vegetation }\end{array}$ & \\
\hline $\mathrm{Si}$ & Weathering & Medium via vegetation & \\
\hline $\mathrm{Al}$ & Weathering & Medium & \\
\hline $\mathrm{Fe}$ & Weathering & Medium & $\begin{array}{l}\mathrm{Fe}^{2+} \text { (soluble) } \\
\text { Dissolution of } \mathrm{Fe}^{3+} \text { colloids }\end{array}$ \\
\hline $\mathrm{Hg}$ & $\begin{array}{l}\text { Atmospheric deposition } \\
\text { Weathering } \\
\text { Point sources }\end{array}$ & Medium & $\begin{array}{l}\text { Net methylation of mercury to } \\
\text { methylmercury (MeHg) }\end{array}$ \\
\hline $\mathrm{Pb}$ & $\begin{array}{l}\text { Atmospheric deposition } \\
\text { Weathering } \\
\text { Point sources }\end{array}$ & High & \\
\hline $\begin{array}{l}\text { Metals and } \\
\text { trace elements }\end{array}$ & $\begin{array}{l}\text { Weathering } \\
\text { Point sources }\end{array}$ & Medium to high & $\begin{array}{l}\text { In certain cases: } \mathrm{Se}, \mathrm{U}, \mathrm{V}, \mathrm{Mo} \text {, } \\
\text { As, } \mathrm{Sb}, \mathrm{Sn} \text {, etc. }\end{array}$ \\
\hline $\begin{array}{l}\text { Persistent organic pollutants } \\
\text { (POPs) }\end{array}$ & $\begin{array}{l}\text { Atmospheric deposition } \\
\text { Point sources }\end{array}$ & High & \\
\hline
\end{tabular}

quantity (Dosskey and Bertsch 1994; Boyer and others 1997; Hinton and others 1998; Köhler and others 2009; Strohmeier and others 2013; Dick and others 2015) and quality (Sanderman and others 2009; Kothawala and others 2015), whereas stream organic C is similar to riparian organic C both quantitatively and qualitatively. Second, estimates of annual net ecosystem production (NEP, Chapin and others 2006) in RZs appear more than sufficient to support annual exports of stream organic C
(Ledesma and others 2015), highlighting the key role of the riparian vegetation for OM accumulation and transport. Furthermore, much of the organic $\mathrm{C}$ found in boreal streams is of recent origin, as determined by ${ }^{14} \mathrm{C}$ measurements (Schiff and others 1998; Ledesma and others 2015). Finally, most of the C stored in boreal forest upslopes is potentially derived from roots and mycorrhizal fungi (Clemmensen and others 2013), but RZs are generally hypoxic and do not support mycorrhizae 


\section{A Organic matter accumulation/export}

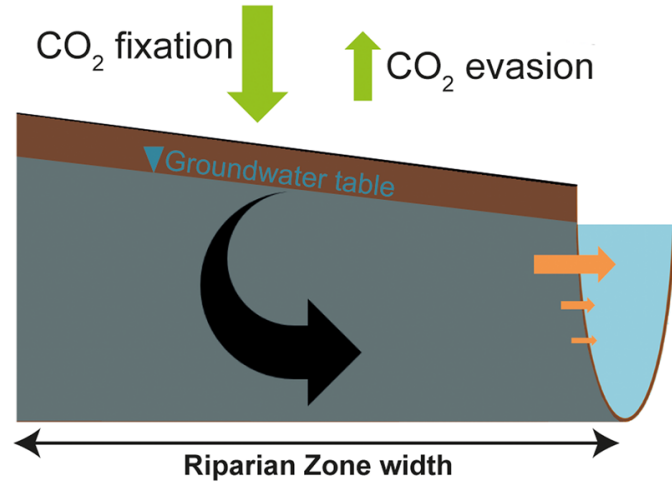

B Retention
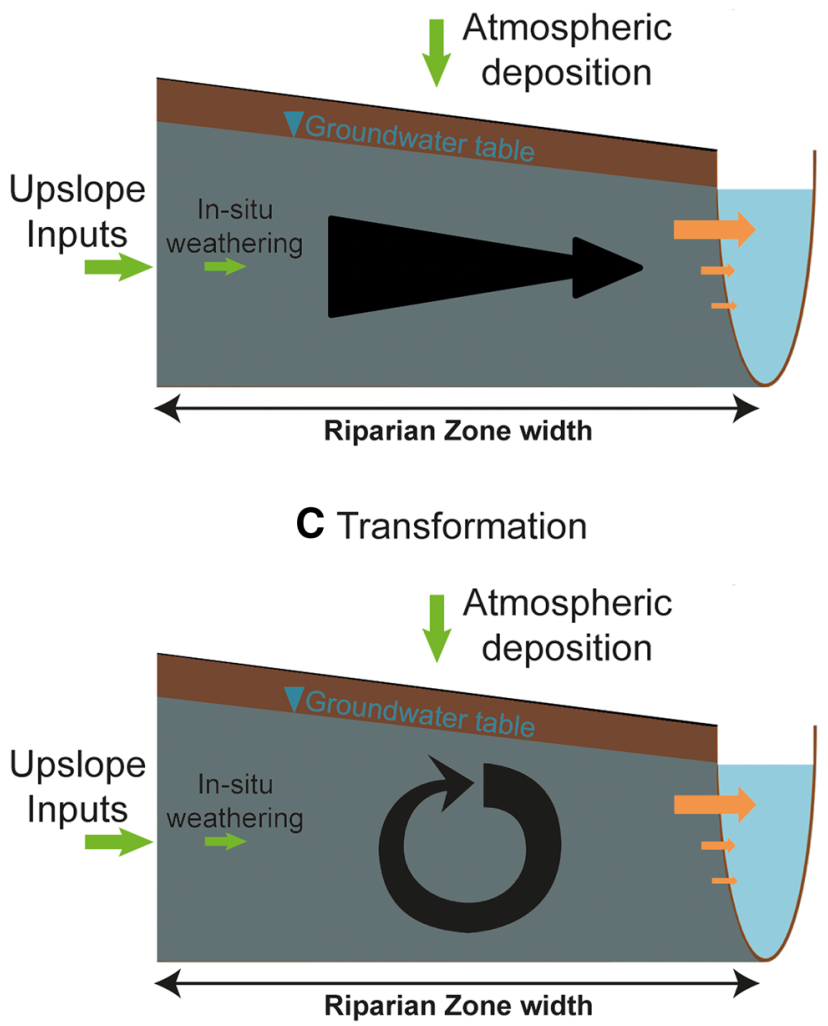

Figure 3. Conceptualization of riparian zone (RZ) biogeochemical functions: A organic matter accumulation and export (from leaf litter, plant root exudates, and soil microflora), B retention of chemical elements and compounds via interaction with organic matter, and $\mathbf{C}$ transformation of chemical elements and compounds via redox reactions. Orange arrows represent lateral water and solute fluxes from RZs to streams, concentrated in a relatively narrow layer within the riparian profile, the Dominant Source Layer. Black arrows represent each of the specified functions (Color figure online).

(Brady and Weil 1999). This provides further evidence for the decoupling of the upslope and riparian $\mathrm{C}$ cycles and implies that the terrestrial $\mathrm{C}$ exported to streams is regulated in fundamentally different ways than the $\mathrm{C}$ stored in the surrounding catchment.
Organic N, organic $\mathrm{P}$, and organic sulfur (S) dynamics are similar to those of organic $\mathrm{C}$, as they are all part of the OM produced in and transported from RZs to streams (Baldwin and Mitchell 2000; Hagedorn and others 2000; Skyllberg and others 2003; Petrone and others 2007). Although there 
can be similarities in the behavior of organic forms of, for example, $\mathrm{C}$ and $\mathrm{N}$ in forest soils (Kothawala and Moore 2009), the two elements do not always display synchronous dynamics (McDowell and others 1998; Michalzik and Matzner 1999). This can be attributed to the relative importance that internal cycling has on the different elements that compose $\mathrm{OM}$ as, for example, most $\mathrm{N}$ and $\mathrm{P}$ mobilized to boreal streams originates from internal cycling (Blackburn and others 2017).

\section{Retention of Chemical Elements and Compounds Via Interactions with Organic Matter in the Riparian Zone}

The potential for a soil to store positively charge chemical species is defined by the cation exchange capacity (CEC), an estimate of the total negative charge given by OM and clay minerals. In RZs, the functional groups creating CEC belong mostly to OM. These are hydroxyl $(-\mathrm{OH})$ and carboxyl $(-\mathrm{COOH})$ groups that interchange their protons with cations in the solution in a pH-dependent process (Skyllberg and others 2001). This, in turn, creates the potential for retention of cationic elements in the RZ (Figure 3B). The retention process is complex, especially in acidic soils typical of boreal RZs where aluminum (Al) species play an important, $\mathrm{pH}$-dependent role in the exchange mechanism (Ross and others 2008). Flocculationprecipitation processes mediated by OM can also be responsible for element retention (Selim and Kingery 2003). For the purpose of the conceptualization, we assume a scale of element-specific retention potential, where conduit flow through the RZ would be at the lower end of the scale (no retention) and no transport at all would be at the upper end of the scale (full retention) (Table 1).

It is difficult to find examples of compounds that simply pass through the RZ without alteration as in a conduit system. Some studies suggest that the stream signal of the base cations calcium (Ca), magnesium $(\mathrm{Mg})$, and sodium $(\mathrm{Na})$ is controlled by an upslope mineralogical signal given the small temporal variation in $\mathrm{RZ}$ solute concentrations similar to upslope concentrations (Burns and others 1998; Ledesma and others 2013; Lidman and others 2016). The RZ would seem to act as a mere conduit in this case continuously equilibrating to the upslope release of $\mathrm{Ca}, \mathrm{Mg}$, and $\mathrm{Na}$. Potassium (K) would also be located at the low side of the retention scale, and it is more strongly influenced by vegetation recirculation than other base cations (Tukey 1970). Silicon (Si) has a low affinity for OM but has been shown to be retained within the RZ via accumulation by plants (Struyf and Conley 2009; Struyf and others 2009).

In general, the affinity of heavy metal cations for OM binding is larger than that of alkali and alkaline cations and tends to increase with oxidation state (Förstner and Wittmann 2012). These organophilic properties would situate these elements in the medium to high range within the RZ retention scale (Table 1). Both $\mathrm{Al}$ and iron (Fe), quantitatively important metals in boreal catchments (Löfgren and others 2010; Temnerud and others 2014), have been shown to be retained in RZs (Mulder and others 1991; Pellerin and others 2002; Knorr 2013; Riedel and others 2013). Mercury (Hg) also tends to bind to OM (Lee and others 2000; Ravichandran 2004) and can be retained in organic soils (Johansson and others 2001; Skyllberg and others 2006). Lead $(\mathrm{Pb})$ can be highly retained in RZs (Klaminder and others 2006) and would appear in the upper end of the retention scale. Depending on $\mathrm{pH}$ and redox behavior, other organophilic metals including toxic metals, trace elements, and heavy metals in general can be expected to be moderately to highly retained in RZs (Neubauer and others 2013; Köhler and others 2014; Lidman and others 2014, 2016). Persistent organic pollutants (POPs) such as polychlorinated biphenyls (PCBs) and legacy pesticides have high affinity to bind to OM via hydrophobic interactions and are usually highly retained in RZs (Bergknut and others 2011).

Many of the chemical elements and compounds discussed above are environmental pollutants that in many cases are toxic to biota. Therefore, the retention function makes RZs extraordinary buffers of surface water pollution. However, the high affinity for OM also allows for co-transport when $\mathrm{OM}$ is solubilized and mobilized to the streams, for example, in the case of $\mathrm{Al}$ (Cory and others 2007), trace elements (Köhler and others 2014), and potentially POPs. The combination of long-term pollutant accumulation, disturbances such as ditching, and future climate with predicted increase in precipitation and OM leaching could have farreaching and unknown consequences for surface water quality in boreal regions unless a conceptual framework suitable for organizing information and making predictions is provided.

\section{Transformation of Chemical Elements and Compounds Via Redox Reactions in the Riparian Zone}

Microbial oxygen consumption in riparian soils is positively correlated with OM content (Gurwick 
and others 2008), with especially high rates of biochemical processing in highly organic soils. Thus, OM is the essential substrate for microbes in reduction-oxidation processes. Although RZs are dominated by hypoxia due to shallow water levels and microbial activity, transient oxic-hypoxic conditions can occur as a consequence of groundwater table fluctuations. This process is especially important in the Dominant Source Layer (Figures $1 \mathrm{~A}, 2 \mathrm{~B})$. Oxygen $\left(\mathrm{O}_{2}\right)$ is energetically the most preferable electron acceptor for reduction reactions under the frequently occurring hypoxic conditions, but inorganic forms of $\mathrm{N}, \mathrm{S}$, or Fe (among others) can act as alternative electron acceptors driving important elemental transformations (Hedin and others 1998). Different OM compounds at different reduction states act as electron donors during both hypoxic and oxic conditions. As in the case of cation exchange ascribed to the retention function, $\mathrm{pH}$ plays an important role in reduction-oxidation processes because many redox reactions involve the transfer of one or more protons, which makes these reactions $\mathrm{pH}$-dependent (Becking and others 1960).

Reducing conditions in the $\mathrm{RZ}$ can lead to the formation of methane $\left(\mathrm{CH}_{4}\right)$, a potent greenhouse gas which could be either transferred laterally to the stream or released to the atmosphere (Hope and others 2001; Sun and others 2013), but also reoxidized to carbon dioxide $\left(\mathrm{CO}_{2}\right)$ before leaving the system. $\mathrm{CO}_{2}$ is the main product of OM oxidation and a subproduct of most other redox reactions. The lateral transfer of inorganic $\mathrm{C}$ including $\mathrm{CO}_{2}$ from the terrestrial to the aquatic system is quantitatively important in regional and global C budgets (Wallin and others 2013), and it appears that most of it could originate in the RZ (Leith and others 2015).

Inorganic $\mathrm{N}$, largely in the form of nitrate $\left(\mathrm{NO}_{3}{ }^{-}\right)$, has been widely studied in riparian systems (for example, Cirmo and McDonnell 1997). RZs effectively remove $\mathrm{NO}_{3}{ }^{-}$through uptake and denitrification (Vought and others 1994), a process driven by the local occurrence of hypoxic zones in conjunction with labile organic C (McClain and others 2003). Denitrification results in the production of inert molecular $\mathrm{N}$ gas $\left(\mathrm{N}_{2}\right)$, although nitrous oxide $\left(\mathrm{N}_{2} \mathrm{O}\right)$, a powerful greenhouse gas, can also be produced (Lashof and Ahuja 1990; Hedin and others 1998). $\mathrm{NO}_{3}{ }^{-}$removal is important for reducing the impact of $\mathrm{N}$ export in agricultural systems (for example, Ocampo and others 2006; Duval and Hill 2007; Pinay and others 2015), but the process has also been shown in RZs in natural temperate and boreal catchments (for example, Simmons and others 1992; Fölster 2000; Ranalli and Macalady 2010). Given the potential importance of RZs for the breakdown of OM to $\mathrm{CO}_{2}$, there is also the possibility for these environments to generate ammonium $\left(\mathrm{NH}_{4}{ }^{+}\right)$via $\mathrm{OM}$ mineralization and elevated levels of $\mathrm{NH}_{4}{ }^{+}$have been observed in riparian wells under hypoxic conditions (Mulholland 1992). In boreal headwaters, $\mathrm{NH}_{4}{ }^{+}$production in hydrologically active layers of the RZ may serve as the dominant source of inorganic $\mathrm{N}$ to streams (Blackburn and others 2017). Nonetheless, $\mathrm{NH}_{4}{ }^{+}$production and accumulation has also been reported in RZs from different biomes (for example, tropical rain forest catchments) (McDowell and others 1992; McClain and others 1994), supporting the universality of many of the processes presented here.

Hypoxic conditions in RZs can also lead to a reduction in the oxidation state of metals, which can have far-reaching consequences for their mobility and biogeochemistry. For example, the mobility of $\mathrm{Fe}$ is enhanced under such conditions because of the reduction to the more soluble $\mathrm{Fe}^{2+}$ form. Manganese $(\mathrm{Mn})$ can also be expected to be generally more mobile under more reducing conditions (Björkvald and others 2008).

Episodic oxic conditions can lead to the oxidation of reduced organic $\mathrm{S}$ compounds and the formation of sulfate $\left(\mathrm{SO}_{4}{ }^{2-}\right)$ (Devito and Hill 1997; Ledesma and others 2016), which controls the solubility of $\mathrm{OM}$ and the acidification status of soils and waters (Clark and others 2006; Futter and others 2014). Similarly, episodic changes in the redox conditions of the RZ have profound effects on the oxidation state and, consequently, the mobility of selenium (Se), both an essential and potentially toxic element to biota (Lidman and others 2011).

RZs do not always play the role of buffering water bodies. On the contrary, they can potentially contribute to stream pollution and toxicity, depending on the degree of hydrological connectivity and availability of OM to support microbial activity. One of the most important examples relates to Hg. Fluctuating oxic-hypoxic conditions in RZs and the presence of OM, which acts as an energy source and co-transports $\mathrm{Hg}$, are ideal for the net methylation of mercury (Bishop and others 1995; Eklöf and others 2015). Methylmercury (MeHg) is a highly toxic species of $\mathrm{Hg}$ with high potential for bioaccumulation. Methylation is carried out by microbes such as sulfate-reducing bacteria and therefore coupled to the availability of OM substrate (the electron donor) and electron acceptors such as $\mathrm{SO}_{4}{ }^{2-}$. In boreal catchments, where atmospheric deposition of both $\mathrm{Hg}$ and 
Table 2. Driving Factors and Dominant Processes in the Riparian Zone and Their Effects on the Dominant Source Layer (DSL) Over a Range of Timescales

\begin{tabular}{llll}
\hline Timescale & Driving factors & Dominant riparian zone processes & Effect on DSL \\
\hline Millennia & $\begin{array}{l}\text { Topography } \\
\text { Geology }\end{array}$ & $\begin{array}{l}\text { Restricted water flows and development } \\
\text { of areas of poor drainage }\end{array}$ & \\
& $\begin{array}{l}\text { Climate } \\
\text { Vegetation }\end{array}$ & $\begin{array}{l}\text { Accumulation of organic matter in areas } \\
\text { of restricted flow } \\
\text { Development of reducing environments }\end{array}$ & Gradual rise \\
Decades & $\begin{array}{l}\text { Disturbances } \\
\text { (fire, ditching, forest } \\
\text { harvesting) }\end{array}$ & $\begin{array}{l}\text { Changes in oxygenation } \\
\text { Changes in organic matter mineralization } \\
\text { Alteration in hydrological connectivity }\end{array}$ & $\begin{array}{c}\text { Abrupt and long-lasting changes } \\
\text { both up and down }\end{array}$ \\
Annual & $\begin{array}{l}\text { Seasonality of tempera- } \\
\text { ture and runoff }\end{array}$ & $\begin{array}{l}\text { Retention of elements and compounds } \\
\text { Reduction-oxidation processes }\end{array}$ & $\begin{array}{c}\text { Predictable seasonal cycle based on } \\
\text { dominant hydrograph }\end{array}$ \\
$\begin{array}{l}\text { Event } \\
\text { (hours-days) }\end{array}$ & $\begin{array}{l}\text { Storm and snowmelt } \\
\text { events }\end{array}$ & Mobilization and transport & $\begin{array}{c}\text { Activation of more conductive stra- } \\
\text { ta }\end{array}$
\end{tabular}

There is a super-position of effects as processes occurring at a longer timescale (for example, organic matter accumulation over centuries) influence the behavior of the DSL at shorter timescales (for example, long-lasting shifts due to ditching or other disturbance).

$\mathrm{SO}_{4}{ }^{2-}$ has been relatively high during the industrial period (Mylona 1996; Johansson and others 2001), the formation of MeHg in RZs is a present and a future threat for aquatic ecosystems.

\section{The role of Timescales and Hydrology in Relation to Riparian Biogeochemical Functions}

As proposed by Burt (2005), the RZ acts, paradoxically, as both a conduit and a barrier between the terrestrial and the aquatic environments. We also highlight the importance of transformations within the $\mathrm{RZ}$ and argue that the proposed paradox is ultimately regulated by hydrology; specifically, the time water takes to transit the landscape and the degree of connectivity between terrestrial and aquatic environments (Table 2).

Over the long term (centuries to millennia), RZ function is controlled by the manner in which climate, vegetation, and topography mediate hydrology. When there is sufficient precipitation, OM and atmospherically deposited pollutants can build up in areas of poor drainage. OM buildup is facilitated by slow drainage, which limits oxygen availability, thereby promoting reducing conditions and slowing decomposition rates (DeLuca and Boisvenue 2012). Because OM increases the water holding capacity of the soil, there is a feedback process that can further increase OM buildup.
Over decades to centuries, previously retained or accumulated compounds can be slowly detached from the riparian OM matrix due to changes in physicochemical equilibria and leached to the stream in the same or different chemical form. Depending on the strength of the association between the particular element or compound and the riparian OM, this process can be delayed for a few years, decades, or even centuries, as suggested for $\mathrm{Pb}$ (Klaminder and others 2006). Over a similar time period, disturbances including fire, ditching, or upslope and riparian forest harvesting can alter the hydrological connectivity between zones of OM buildup and the stream. For example, widespread ditching could have had two important consequences: (1) a change in the hydrological connectivity and transit times between soils and streams and (2) a shift in the soil redox status toward more extensive and frequent oxic conditions. As reduction-oxidation processes are key to functioning of terrestrial-aquatic transition zones (Hedin and others 1998), changes in redox state have likely had important implications for material cycling and water quality in the region (for example, Lidman and others 2014).

Over an annual timescale, the manner in which weather and precipitation patterns control flows through the RZ are the primary control on stream chemistry. During relatively long periods of low flow or summer dryness, transport and oxygen 
availability are both limited and there is often time to transform (or remove as a particular case of transformation) specific compounds (for example, $\mathrm{NO}_{3}{ }^{-}, \mathrm{MeHg}$ ).

In the short term (hours-days), hydrological events (rain storms and spring floods) mobilize compounds stored in the RZ. These events are typically too rapid to significantly alter the redox environment in the RZ. Events can, for example, export accumulated elements or compounds that would otherwise be degraded or transformed if there was enough time, turning the RZ function from retention or transformation to conduit (as a particular case in the retention scale). Thus, the biogeochemically processed substances in the RZ are mostly mobilized to the stream during relatively short periods of the year (Boyer and others 1997; Köhler and others 2008).

Bearing in mind the role of hydrology and how connectivity and transit times influence retention, transformation, and mobilization of solutes can help in understanding how RZs can act as both conduits and barriers, and so also as both sinks and sources of pollutants (for example, Cory and others 2007). Hydrological processes governed by longer timescales can both amplify or diminish hydrological effects observed at shorter timescales. For example, future climate in the boreal region will tend to increase the frequency of snowmelt episodes but these will be of less intensity (Oni and others 2015).

\section{Conceptualizing Riparian Zone Spatial HeTEROGENEITY}

The rate and spatial pattern of soil OM accumulation is typically heterogeneous within catchments (Zimmer and others 2013; Herndon and others 2015). The RZ extent is therefore heterogeneously distributed along streams (Figure 1B) as driven by local hydromorphological characteristics. For example, wider RZs are related to shallower groundwater tables and a larger topographic wetness index (TWI), a surrogate for shallow groundwater table positions (Grabs and others 2012; Ledesma and others 2015). These relationships are not surprising, but their implications are often ignored.

To explore the consequences of spatial heterogeneity in the RZ, the lateral extent of organic soils from the stream edge to the transition to mineral podzols following the local topographical slope was measured in ten forest hillslopes located in the boreal catchment from which our conceptualization was developed. Because of the large hetero- geneity in hydromorphological and topographical characteristics of the hillslopes, the extent of the RZ width varied widely, between only about $2 \mathrm{~m}$ to as much as $40 \mathrm{~m}$, or on average $19 \pm 15 \mathrm{~m}$ (Ledesma and others 2015). At the same time, the actual OM content of those organic riparian soils, defined by their C content, was somewhat variable and in general correlated positively with the extent of the RZ. Typically, the C content of the Dominant Source Layer of relatively flat and wet RZs was not below $30 \%$ and it could reach more than 50\% (Ledesma and others 2015). This contrasts strongly with the corresponding upslope podzols, for which $\mathrm{C}$ content below the narrow organic topsoil horizon is typically below 3\% (unpublished data from the same catchment). These simple measurements provide a clear picture of RZ spatial heterogeneity and importance for biogeochemical processing and surface water chemistry in relation to the rest of the catchment.

As $\mathrm{OM}$ is the key in the riparian biogeochemical control, the potential magnitude of the RZ functions is larger in wider RZs. In other words, the wider the RZ (which serves as a proxy to OM content), the longer the transit distance of the water in organic-rich layers and the larger the potential for retention or transformation of elements and chemical compounds. Hence, the heterogeneous distribution of RZs in space translates into a heterogeneous intensity of the RZ biogeochemical functions. These functions are important for soil water chemistry and also influence surface water quality in wet areas hydrologically connected to streams (Figure 1C), particularly if they occur within the Dominant Source Layer, a concept that explicitly recognize the importance of the vertical dimension for hydrological connectivity.

Bernhardt and others (2017) recently criticized the tendency of researchers to only consider the spatial or temporal component of biogeochemical variation, referring to the hot spot and hot moment concepts introduced by McClain and others (2003). Our conceptualization of the Dominant Source Layer integrates both process and transport phenomena. Thus, it addresses the recommendation from Bernhardt and others (2017) to incorporate both spatial and temporal components, as well as the interplay between resource pools and hydrological pattern, and in this way illustrates how important 'ecosystem control points' can emerge in low-gradient boreal landscapes. So as to specifically characterize the RZ structures and processes that will allow identifying 'ecosystem control points' such as the Dominant Source Layer, we briefly 
review and suggest methods for mapping hydrological connectivity and RZ areas below.

\section{Methods for Mapping Hydrological Connectivity and Riparian Zone Areas}

Heterogeneity in hydrological connectivity between the RZ and aquatic environment must be recognized in any assessment of RZ function. Blume and van Meerveld (2015) reviewed different methods that have been used to study subsurface hydrological connectivity, including trenches, distributed groundwater table measurements, tracer experiments, and stream chemistry measurements. These methods have difficulties handling the large variability in hillslope responses. Recent advances in remote sensing techniques provide new opportunities to map hydrological connectivity. In particular, high-resolution Digital Elevation Models (DEMs) based on Light Detection and Ranging (LiDAR) data can be used to identify subsurface flow direction and accumulation (Ali and Roy 2010). This information can, in turn, be used to delineate wet areas (Ågren and others 2014; Pinay and others 2015), as well as to estimate longitudinal/lateral connectivity (Jencso and others 2009) and depth to groundwater (Grabs and others 2012). Estimating groundwater levels is essential to identify the vertical position and extent of the Dominant Source Layer. Monitoring of groundwater levels is an alternative to establish the relationship between stream flow and groundwater tables of individual riparian sites that will allow estimating Dominant Source Layers empirically (Figure 2A). We argue that identifying the spatial structure of vertical connectivity to the stream within the riparian profile is at least as important as mapping wet areas in the catchment surface and should be considered in any assessment of headwater hydrological connectivity.

Linking hydrological transport to RZ width and OM properties, however, is still challenging. Precise RZ width estimates are usually based on field observations in a number of selected transects within a catchment (McGlynn and Seibert 2003; Ledesma and others 2015). This method is timeconsuming and does not produce a complete RZ delineation. Terrain attributes like the recently developed depth-to-water (DTW) index, which represents the elevation difference between the soil surface and the nearest open water body, appear to be more effective than the traditional TWI in determining soil types (Murphy and others 2011; Ågren and others 2015) and could be a promising tool to map RZs.

\section{IMPLICATIONS FOR RIPARIAN UPSCALING AND LAND MANAgEMENT}

RZs have been traditionally conceptualized as linear features buffering lotic water bodies. These lumped conceptualizations of the RZ from single representative riparian profiles or single $\mathrm{RZ}$ widths have often been used to investigate the links between riparian and stream chemistry and hydrology (Boyer and others 1996; Smart and others 2001; Sanderman and others 2009; Seibert and others 2009; Gundersen and others 2010). However, given the large spatial heterogeneity in RZ distribution and function, this lumped approach leads to oversimplifications when upscaling results to catchments and landscapes (Blume and van Meerveld 2015). As such, spatially explicit and distributed representations of RZ structures and functions are needed to accurately upscale the integrated riparian signal to the catchment level. More efforts should be made using indexes based on remote sensing techniques to map wet areas and water flowpaths and to try to differentiate histosols from mineral soils, the typical soil configuration in boreal forest catchments, and thereby RZs. This would help characterizing hydrological connectivity and the landscape ordination of RZ heterogeneity along the stream continuum, facilitating riparian upscaling. Once hydrological connectivity and RZ ordination are delineated, hypotheses based on the conceptual model presented here can be tested empirically. The idea of a Dominant Source Layer is one under-explored concept which could explain differences in stream chemistry observed between wet and dry years (for example, Köhler and others 2008) or following forest clear-cutting (for example, Schelker and others 2012). Combining estimates of lateral water fluxes and solute concentration measurements, in both RZs and upslope soils, will allow for evaluating mass balances and potential biogeochemical processes occurring in relevant areas of the landscape. From a surface water quality perspective, measurement efforts should then be made only on those specific areas of the landscape that contribute the most to water and solute fluxes to the stream.

Forestry, an important economic activity and the most common type of management in boreal forests (Gauthier and others 2015; Futter and others 2016) can amplify $\mathrm{Hg}$ mobilization (Eklöf and others 2012) or increase $\mathrm{NO}_{3}{ }^{-}$leaching (Keller and others 2006; Futter and others 2010). The mobilization of $\mathrm{Hg}$ is associated with both a higher methylation potential and an increase in co-transportation with $\mathrm{C}$ following the corresponding rise 
in groundwater tables after harvesting. Leaching of $\mathrm{NO}_{3}{ }^{-}$is favored by the decrease in plant uptake and increased hydrological transport. So-called riparian buffer strips are an important management practice in forestry to avoid adverse impacts of forest harvesting on aquatic environments (Kreutzweiser and others 2008; Gundersen and others 2010). For biodiversity and aquatic protection purposes, it has been suggested that unharvested buffers should be between 30 and $200 \mathrm{~m}$ wide (Castelle and others 1994). Although different buffer widths might be recommended based on local variations in features such as slope (Hazlett and others 2008), fixed width buffers are often applied without consideration of the spatial heterogeneity of the RZ (Richardson and others 2012; Kuglerová and others 2014a). Fixed width buffers have been used as they are easily implemented, but new conceptual understanding of riparian functioning, together with computational techniques and digital maps, provide the tools needed to optimize buffer designs that move beyond fixed width approaches (Kuglerová and others 2014a). Indeed, recent studies suggest that riparian buffers closely resembling their natural regimes should vary in width, tree-age structure, and species composition across relatively small spatial scales to optimize protection (Kreutzweiser and others 2012). In light of the hydrological, biogeochemical, and spatial heterogeneity of RZs presented here for locally adapted management, improved water quality protection can be achieved more efficiently. By including more mechanistic insights related to local RZ characteristics concerning hydrological connectivity, storage and transformation of elements and compounds, and susceptibility to perturbation, forest management can take action to minimize impacts on stream water quality (Laudon and others 2016).

Conceptualizations of forest biogeochemical processes can be an important tool for communicating the consequences of anthropogenic activities including forestry on water quality (Futter and others 2016). The conceptualization presented here, which has been mainly, but not only, exemplified by boreal forest headwaters, should also be useful for other similar areas (for example, low-gradient, peat-rich RZs in temperate and tropical forests) and other land-use types within the boreal biome (agricultural systems and lakes). In essence, hydrological connectivity and biogeochemical functions of OM-rich areas such as the RZs presented here are universal, extending the applicability of these concepts to a broad scale. However, it would still be necessary to verify our conceptualization in similar areas, but also most interesting to assess its utility in environments in which RZs are not defined by OM content, there is no relationship between groundwater tables and stream flow, runoff generation is dominated by overland or subsurface unsaturated flow, or climate is warm and dry. Particularly, it would be most valuable to test whether the Dominant Source Layer concept is applicable in such environments. A refined picture of RZs in terms of hydrological connectivity, biogeochemical functioning, and spatial heterogeneity is an essential prerequisite for ecologically sustainable and economically effective land management that preserves surface water quality. This includes the specific recognition and identification of the Dominant Source Layer, a deeper understanding of the processes of retention and transformation and, foremost, an adaptive consideration of RZ spatial distribution.

\section{ACKNOWLEDGEMENTS}

This study is part of the ForWater (Formas) project with additional funding from Future Forest, VR (SITES), FOMA, SKB, and the Horizon 2020 Landmark program. We thank Sarah Josefsson and Joachim Audet for helpful discussions. Finally, we thank two anonymous referees for two rigorous and valuable reviews. Their comments and suggestions improved the quality of this paper.

\section{OPEN ACCESS}

This article is distributed under the terms of the Creative Commons Attribution 4.0 International License (http://creativecommons.org/licenses/by/ $4.0 /$ ), which permits unrestricted use, distribution, and reproduction in any medium, provided you give appropriate credit to the original author(s) and the source, provide a link to the Creative Commons license, and indicate if changes were made.

\section{REFERENCES}

Adams MA. 2013. Mega-fires, tipping points and ecosystem services: managing forests and woodlands in an uncertain future. For Ecol Manag 294:250-61.

Ågren AM, Lidberg W, Strömgren M, Ogilvie J, Arp PA. 2014. Evaluating digital terrain indices for soil wetness mapping-a Swedish case study. Hydrol Earth Syst Sci 18:3623-34.

Ågren AM, Lidberg W, Ring E. 2015. Mapping temporal dynamics in a forest stream network-implications for riparian forest management. Forests 6:2982-3001.

Ali GA, Roy AG. 2010. Shopping for hydrologically representative connectivity metrics in a humid temperate forested catchment. Water Resour Res 46:W12544. 
Apps MJ, Kurz WA, Luxmoore RJ, Nilsson LO, Sedjo RA, Schmidt R, Simpson LG, Vinson TS. 1993. Boreal forest and tundra. Water Air Soil Pollut 70:39-53.

Åström M, Aaltonen EK, Koivusaari J. 2001. Effect of ditching operations on stream-water chemistry in a boreal forested catchment. Sci Total Environ 279:117-29.

Baldwin DS, Mitchell AM. 2000. The effects of drying and reflooding on the sediment and soil nutrient dynamics of lowland river-floodplain systems: a synthesis. Regul Rivers Res Manag 16:457-67.

Becking L, Kaplan IR, Moore D. 1960. Limits of the natural environment in terms of $\mathrm{pH}$ and oxidation-reduction potentials. J Geol 68:243-84.

Benstead JP, Leigh DS. 2012. An expanded role for river networks. Nat Geosci 5:678-9.

Bergknut M, Laudon H, Jansson S, Larsson A, Gocht T, Wiberg K. 2011. Atmospheric deposition, retention, and stream export of dioxins and PCBs in a pristine boreal catchment. Environ Pollut 159:1592-8.

Bernal S, von Schiller D, Martí E, Sabater F. 2012. In-stream net uptake regulates inorganic nitrogen export from catchments under base flow conditions. J Geophys Res Biogeosci 117:G00N05.

Bernhardt ES, Blaszczak JR, Ficken CD, Fork ML, Kaiser KE, Seybold EC. 2017. Control points in ecosystems moving beyond the hot spot hot moment concept. Ecosystems . doi:10. 1007/s10021-016-0103-y (published online).

Bishop K, Lee YH, Pettersson C, Allard B. 1995. Terrestrial sources of methylmercury in surface waters-the importance of the riparian zone on the Svartberget catchment. Water Air Soil Pollut 80:435-44.

Bishop K, Seibert J, Köhler S, Laudon H. 2004. Resolving the double Paradox of rapidly mobilized old water with highly variable responses in runoff chemistry. Hydrol Process 18:185-9.

Bishop K, Buffam I, Erlandsson M, Fölster J, Laudon H, Seibert J, Temnerud J. 2008. Aqua Incognita: the unknown headwaters. Hydrol Process 22:1239-42.

Bishop K, Seibert J, Nyberg L, Rodhe A. 2011 . Water storage in a till catchment. II: Implications of transmissivity feedback for flow paths and turnover times. Hydrol Process 25:3950-9.

Björkvald L, Buffam I, Laudon H, Mörth CM. 2008. Hydrogeochemistry of Fe and $\mathrm{Mn}$ in small boreal streams: the role of seasonality, landscape type and scale. Geochimica Et Cosmochimica Acta 72:2789-804.

Blackburn M, Ledesma JLJ, Näsholm T, Laudon H, Sponseller RA. 2017. Evaluating hillslope and riparian contributions to dissolved nitrogen $(\mathrm{N})$ export from a boreal forest catchment. J Geophys Res Biogeosci 122:324-39.

Blume T, van Meerveld HJ. 2015. From hillslope to stream: methods to investigate subsurface connectivity. Wiley Interdiscip Rev Water 2:177-98.

Boyer EW, Hornberger GM, Bencala KE, McKnight D. 1996. Overview of a simple model describing variation of dissolved organic carbon in an upland catchment. Ecol Model 86:183-8.

Boyer EW, Hornberger GM, Bencala KE, McKnight DM. 1997. Response characteristics of DOC flushing in an alpine catchment. Hydrol Process 11:1635-47.

Brady NC, Weil RR. 1999. The nature and properties of soils. Upper Saddle River: Prentice Hall.

Burns DA, Hooper RP, McDonnell JJ, Freer JE, Kendall C, Beven K. 1998. Base cation concentrations in subsurface flow from a forested hillslope: the role of flushing frequency. Water Resour Res 34:3535-44.

Burt TP. 2005. A third paradox in catchment hydrology and biogeochemistry: decoupling in the riparian zone. Hydrol Process 19:2087-9.

Castelle AJ, Johnson AW, Conolly C. 1994. Wetland and stream buffer size requirements-a review. J Environ Qual 23:87882.

Chapin FS, Woodwell GM, Randerson JT, Rastetter EB, Lovett GM, Baldocchi DD, Clark DA, Harmon ME, Schimel DS, Valentini R, Wirth C, Aber JD, Cole JJ, Goulden ML, Harden JW, Heimann M, Howarth RW, Matson PA, McGuire AD, Melillo JM, Mooney HA, Neff JC, Houghton RA, Pace ML, Ryan MG, Running SW, Sala OE, Schlesinger WH, Schulze ED. 2006. Reconciling carbon-cycle concepts, terminology, and methods. Ecosystems 9:1041-50.

Chesworth W. 2008. Encyclopedia of soil science. Dordrecht: Springer.

Cirmo CP, McDonnell JJ. 1997. Linking the hydrologic and biogeochemical controls of nitrogen transport in near-stream zones of temperate-forested catchments: a review. J Hydrol 199:88-120.

Clark JM, Chapman PJ, Heathwaite AL, Adamson JK. 2006. Suppression of dissolved organic carbon by sulfate induced acidification during simulated droughts. Environ Sci Technol 40:1776-83.

Clemmensen KE, Bahr A, Ovaskainen O, Dahlberg A, Ekblad A, Wallander H, Stenlid J, Finlay RD, Wardle DA, Lindahl BD. 2013. Roots and associated fungi drive long-term carbon sequestration in boreal forest. Science 339:1615-18.

Cory N, Laudon H, Köhler S, Seibert J, Bishop K. 2007. Evolution of soil solution aluminum during transport along a forested boreal hillslope. J Geophys Res Biogeosci 112:G03014.

DeLuca TH, Boisvenue C. 2012. Boreal forest soil carbon: distribution, function and modelling. Forestry 85:161-84.

Devito KJ, Hill AR. 1997. Sulphate dynamics in relation to groundwater-surface water interactions in headwater wetlands of the southern Canadian Shield. Hydrol Process 11:485-500.

Dick JJ, Tetzlaff D, Birkel C, Soulsby C. 2015. Modelling landscape controls on dissolved organic carbon sources and fluxes to streams. Biogeochemistry 122:361-74.

Dosskey MG, Bertsch PM. 1994. Forest sources and pathways of organic-matter transport to a blackwater stream-a hydrologic approach. Biogeochemistry 24:1-19.

Duval TP, Hill AR. 2007. Influence of base flow stream bank seepage on riparian zone nitrogen biogeochemistry. Biogeochemistry 85:185-99.

Eklöf K, Kraus A, Weyhenmeyer GA, Meili M, Bishop K. 2012. Forestry influence by stump harvest and site preparation on methylmercury, total mercury and other stream water chemistry parameters across a boreal landscape. Ecosystems 15:1308-20.

Eklöf K, Kraus A, Futter M, Schelker J, Meili M, Boyer EW, Bishop K. 2015. Parsimonious model for simulating total mercury and methylmercury in boreal streams based on riparian flow paths and seasonality. Environ Sci Technol 49:7851-9.

Erlandsson M, Oelkers EH, Köhler SJ, Sverdrup H, Belyazid S, Ledesma JLJ, Bishop K. 2016. Spatial and temporal variations of base cation release from chemical weathering on a hillslope scale. Chem Geol 441:1-13. 
Fölster J. 2000. The near-stream zone is a source of nitrogen in a Swedish forested catchment. J Environ Qual 29:883-93.

Förstner U, Wittmann GTW. 2012. Metal pollution in the aquatic environment. Berlin: Springer.

Futter MN, Ring E, Högbom L, Entenmann S, Bishop KH. 2010. Consequences of nitrate leaching following stem-only harvesting of Swedish forests are dependent on spatial scale. Environ Pollut 158:3552-9.

Futter MN, Valinia S, Löfgren S, Köhler SJ, Fölster J. 2014. Long-term trends in water chemistry of acid-sensitive Swedish lakes show slow recovery from historic acidification. Ambio 43:77-90.

Futter MN, Högbom L, Valinia S, Sponseller RA, Laudon H. 2016. Conceptualizing and communicating management effects on forest water quality. Ambio 45:188-202.

Gauthier S, Bernier P, Kuuluvainen T, Shvidenko AZ, Schepaschenko DG. 2015. Boreal forest health and global change. Science 349:819-22.

Grabs T, Bishop K, Laudon H, Lyon SW, Seibert J. 2012. Riparian zone hydrology and soil water total organic carbon (TOC): implications for spatial variability and upscaling of lateral riparian TOC exports. Biogeosciences 9:3901-16.

Gregory SV, Swanson FJ, McKee WA, Cummins KW. 1991. An ecosystem perspective of riparian zones. Bioscience 41:54051.

Gundersen P, Laurén A, Finér L, Ring E, Koivusalo H, Sætersdal M, Weslien JO, Sigurdsson BD, Högbom L, Laine J, Hansen K. 2010. Environmental services provided from riparian forests in the Nordic countries. Ambio 39:555-66.

Gurwick NP, Groffman PM, Yavitt JB, Gold AJ, Blazejewski G, Stolt M. 2008. Microbially available carbon in buried riparian soils in a glaciated landscape. Soil Biol Biochem 40:85-96.

Hagedorn F, Schleppi P, Waldner P, Fluhler H. 2000. Export of dissolved organic carbon and nitrogen from Gleysol dominated catchments- the significance of water flow paths. Biogeochemistry 50:137-61.

Hazlett P, Broad K, Gordon A, Sibley P, Buttle J, Larmer D. 2008. The importance of catchment slope to soil water $\mathrm{N}$ and $\mathrm{C}$ concentrations in riparian zones: implications for riparian buffer width. Can J For Res 38:16-30.

Hedin LO, von Fischer JC, Ostrom NE, Kennedy BP, Brown MG, Robertson GP. 1998. Thermodynamic constraints on nitrogen transformations and other biogeochemical processes at soilstream interfaces. Ecology 79:684-703.

Herndon EM, Dere AL, Sullivan PL, Norris D, Reynolds B, Brantley SL. 2015. Landscape heterogeneity drives contrasting concentration-discharge relationships in shale headwater catchments. Hydrol Earth Syst Sci 19:3333-47.

Hinton MJ, Schiff SL, English MC. 1998. Sources and flowpaths of dissolved organic carbon during storms in two forested watersheds of the Precambrian Shield. Biogeochemistry 41:175-97.

Hope D, Palmer SM, Billett MF, Dawson JJC. 2001. Carbon dioxide and methane evasion from a temperate peatland stream. Limnol Oceanogr 46:847-57.

Horton RE. 1945. Erosional development of streams and their drainage basins-hydrophysical approach to quantitative morphology. Geol Soc Am Bull 56:275-370.

Jansson R, Laudon H, Johansson E, Augspurger C. 2007. The importance of groundwater discharge for plant species number in riparian zones. Ecology 88:131-9.
Jencso KG, McGlynn BL, Gooseff MN, Wondzell SM, Bencala KE, Marshall LA. 2009. Hydrologic connectivity between landscapes and streams: transferring reach-and plot-scale understanding to the catchment scale. Water Resour Res 45:W04428.

Johansson K, Bergbäck B, Tyler G. 2001. Impact of atmospheric long range transport of lead, mercury and cadmium on the Swedish forest environment. Water Air Soil Poll Focus 1:279-97.

Keller CK, O'Brien R, Havig JR, Smith JL, Bormann BT, Wang D. 2006. Tree harvest in an experimental sand ecosystem: plant effects on nutrient dynamics and solute generation. Ecosystems 9:634-46.

Klaminder J, Bindler R, Laudon H, Bishop K, Emteryd O, Renberg I. 2006. Flux rates of atmospheric lead pollution within soils of a small catchment in northern Sweden and their implications for future stream water quality. Environ Sci Technol 40:4639-45.

Knorr KH. 2013. DOC-dynamics in a small headwater catchment as driven by redox fluctuations and hydrological flow paths-are DOC exports mediated by iron reduction/oxidation cycles? Biogeosciences 10:891-904.

Köhler SJ, Buffam I, Laudon H, Bishop KH. 2008. Climate's control of intra-annual and interannual variability of total organic carbon concentration and flux in two contrasting boreal landscape elements. J Geophys Res Biogeosci 113:G03012.

Köhler SJ, Buffam I, Seibert J, Bishop KH, Laudon H. 2009. Dynamics of stream water TOC concentrations in a boreal headwater catchment: controlling factors and implications for climate scenarios. J Hydrol 373:44-56.

Köhler SJ, Lidman F, Laudon H. 2014. Landscape types and pH control organic matter mediated mobilization of $\mathrm{Al}, \mathrm{Fe}, \mathrm{U}$ and La in boreal catchments. Geochimica Et Cosmochimica Acta 135:190-202.

Kothawala DN, Moore TR. 2009. Adsorption of dissolved nitrogen by forest mineral soils. Can J For Res 39:2381-90.

Kothawala DN, Ji X, Laudon H, Ågren AM, Futter MN, Köhler SJ, Tranvik LJ. 2015. The relative influence of land cover, hydrology, and in-stream processing on the composition of dissolved organic matter in boreal streams. J Geophys Res Biogeosci 120:1491-505.

Kreutzweiser DP, Hazlett PW, Gunn JM. 2008. Logging impacts on the biogeochemistry of boreal forest soils and nutrient export to aquatic systems: a review. Environ Rev 16:157-79.

Kreutzweiser DP, Sibley PK, Richardson JS, Gordon AM. 2012. Introduction and a theoretical basis for using disturbance by forest management activities to sustain aquatic ecosystems. Freshw Sci 31:224-31.

Kuglerová L, Ågren A, Jansson R, Laudon H. 2014a. Towards optimizing riparian buffer zones: ecological and biogeochemical implications for forest management. For Ecol Manag 334:74-84.

Kuglerová L, Jansson R, Åren A, Laudon H, Malm-Renöfält B. 2014b. Groundwater discharge creates hotspots of riparian plant species richness in a boreal forest stream network. Ecology 95:715-25.

Lashof DA, Ahuja DR. 1990. Relative contributions of greenhouse gas emissions to global warming. Nature 344:529-31.

Laudon H, Berggren M, Ågren A, Buffam I, Bishop K, Grabs T, Jansson M, Köhler S. 2011. Patterns and dynamics of dissolved organic carbon (DOC) in boreal streams: the role of processes, connectivity, and scaling. Ecosystems 14:880-93. 
Laudon H, Kuglerová L, Sponseller RA, Futter MN, Nordin A, Bishop K, Lundmark T, Egnell G, Ågren AM. 2016. The role of biogeochemical hotspots, landscape heterogeneity, and hydrological connectivity for minimizing forestry effects on water quality. Ambio 45:152-62.

Lavoie M, Paré D, Fenton N, Groot A, Taylor K. 2005. Paludification and management of forested peatlands in Canada: a literature review. Environ Rev 13:21-50.

Ledesma JLJ, Grabs T, Futter MN, Bishop KH, Laudon H, Köhler SJ. 2013. Riparian zone control on base cation concentration in boreal streams. Biogeosciences 10:3849-68.

Ledesma JLJ, Grabs T, Bishop KH, Schiff SL, Köhler SJ. 2015. Potential for long-term transfer of dissolved organic carbon from riparian zones to streams in boreal catchments. Glob Chang Biol 21:2963-79.

Ledesma JLJ, Futter MN, Laudon H, Evans CD, Köhler SJ. 2016. Boreal forest riparian zones regulate stream sulfate and dissolved organic carbon. Sci Total Environ 560-561:110-22.

Lee YH, Bishop KH, Munthe J. 2000. Do concepts about catchment cycling of methylmercury and mercury in boreal catchments stand the test of time? Six years of atmospheric inputs and runoff export at Svartberget, northern Sweden. Sci Total Environ 260:11-20.

Leith FI, Dinsmore KJ, Wallin MB, Billett MF, Heal KV, Laudon H, Öquist MG, Bishop K. 2015. Carbon dioxide transport across the hillslope-riparian-stream continuum in a boreal headwater catchment. Biogeosciences 12:1881-92.

Lidman F, Mörth CM, Björkvald L, Laudon H. 2011. Selenium dynamics in boreal streams: the role of wetlands and changing groundwater tables. Environ Sci Technol 45:2677-83.

Lidman F, Köhler SJ, Mörth CM, Laudon H. 2014. Metal transport in the boreal landscape-the role of wetlands and the affinity for organic matter. Environ Sci Technol 48:3783-90.

Lidman F, Boily $\AA$, Laudon H, Köhler SJ. 2016. From soil water to surface water-how the riparian zone controls the transport of major and trace elements from a boreal forest to a stream. Biogeosci Discuss . doi:10.5194/bg-2016-494 (in review).

Lidman J, Jonsson M, Burrows RM, Bundschuh M, Sponseller RA. 2017. Composition of riparian litter input regulates organic matter decomposition: implications for headwater stream functioning in a managed forest landscape. Ecol Evol 7:1068-77.

Löfgren S, Zetterberg T. 2011. Decreased DOC concentrations in soil water in forested areas in southern Sweden during 19872008. Sci Total Environ 409:1916-26.

Löfgren S, Cory N, Zetterberg T. 2010. Aluminium concentrations in Swedish forest streams and co-variations with catchment characteristics. Environ Monit Assess 166:609-24.

Luke SH, Luckai NJ, Burke JM, Prepas EE. 2007. Riparian areas in the Canadian boreal forest and linkages with water quality in streams. Environ Rev 15:79-97.

Lupon A, Bernal S, Poblador S, Martí E, Sabater F. 2016. The influence of riparian evapotranspiration on stream hydrology and nitrogen retention in a subhumid Mediterranean catchment. Hydrol Earth Syst Sci 20:3831-42.

Lyon SW, Grabs T, Laudon H, Bishop KH, Seibert J. 2011. Variability of groundwater levels and total organic carbon in the riparian zone of a boreal catchment. J Geophys Res Biogeosci 116:G01020.

Magnani F, Mencuccini M, Borghetti M, Berbigier P, Berninger F, Delzon S, Grelle A, Hari P, Jarvis PG, Kolari P, Kowalski AS,
Lankreijer H, Law BE, Lindroth A, Loustau D, Manca G, Moncrieff JB, Rayment M, Tedeschi V, Valentini R, Grace J. 2007. The human footprint in the carbon cycle of temperate and boreal forests. Nature 447:848-50.

Mattsson T, Kortelainen P, Laubel A, Evans D, Pujo-Pay M, Räike A, Conan P. 2009. Export of dissolved organic matter in relation to land use along a European climatic gradient. Sci Total Environ 407:1967-76.

McClain ME, Richey JE, Pimentel TP. 1994. Groundwater nitrogen dynamics at the terrestrial-lotic interface of a small catchment in the Central Amazon Basin. Biogeochemistry 27:113-27.

McClain ME, Boyer EW, Dent CL, Gergel SE, Grimm NB, Groffman PM, Hart SC, Harvey JW, Johnston CA, Mayorga E, McDowell WH, Pinay G. 2003. Biogeochemical hot spots and hot moments at the interface of terrestrial and aquatic ecosystems. Ecosystems 6:301-12.

McDonnell JJ, McGlynn BL, Kendall K, Shanley J, Kendall C. 1998. The role of near-stream riparian zones in the hydrology of steep upland catchments. In: Kovar K, Tappeiner U, Peters NE, Craig RG, Eds. Hydrology, water resources and ecology in headwaters. Proceedings of the HeadWater'98 Conference 17 held at Meran/Merano, Italy, April 1998. IAHS Publ. no. 248, 1998. pp 173-80.

McDowell WH, Bowden WB, Asbury CE. 1992. Riparian nitrogen dynamics in two geomorphologically distinct tropical rain forest watersheds: subsurface solute patterns. Biogeochemistry 18:53-75.

McDowell WH, Currie WS, Aber JD, Yano Y. 1998. Effects of chronic nitrogen amendments on production of dissolved organic carbon and nitrogen in forest soils. Water Air Soil Pollut 105:175-82.

McGlynn BL, McDonnell JJ. 2003. Quantifying the relative contributions of riparian and hillslope zones to catchment runoff. Water Resour Res 39:1310.

McGlynn BL, Seibert J. 2003. Distributed assessment of contributing area and riparian buffering along stream networks. Water Resour Res 39:1082.

Michalzik B, Matzner E. 1999. Dynamics of dissolved organic nitrogen and carbon in a Central European Norway spruce ecosystem. Eur J Soil Sci 50:579-90.

Moldan F, Wright RF. 1998. Episodic behaviour of nitrate in runoff during six years of nitrogen addition to the NITREX catchment at Gårdsjön, Sweden. Environ Pollut 102:439-44.

Mulder J, Pijpers M, Christophersen N. 1991. Water-flow paths and the spatial-distribution of soils and exchangeable cations in an acid-rain impacted and a pristine catchment in Norway. Water Resour Res 27:2919-28.

Mulholland PJ. 1992. Regulation of nutrient concentrations in a temperate forest stream-roles of upland, riparian, and instream processes. Limnol Oceanogr 37:1512-26.

Murphy PNC, Ogilvie J, Castonguay M, Zhang CF, Meng FR, Arp PA. 2008. Improving forest operations planning through highresolution flow-channel and wet-areas mapping. For Chron 84:568-74.

Murphy PNC, Ogilvie J, Meng FR, White B, Bhatti JS, Arp PA. 2011. Modelling and mapping topographic variations in forest soils at high resolution: a case study. Ecol Model 222:2314-32.

Mylona S. 1996. Sulphur dioxide emissions in Europe 18801991 and their effect on sulphur concentrations and depositions. Tellus Ser B Chem Phys Meteorol 48:662-89.

Naiman RJ, Décamps H. 1997. The ecology of interfaces: riparian zones. Annu Rev Ecol Syst 28:621-58. 
Neubauer E, Köhler SJ, von der Kammer F, Laudon H, Hofmann T. 2013. Effect of $\mathrm{pH}$ and stream order on iron and arsenic speciation in boreal catchments. Environ Sci Technol 47:7120-8.

Nyberg L, Stähli M, Mellander PE, Bishop KH. 2001. Soil frost effects on soil water and runoff dynamics along a boreal forest transect: 1. Field investigations. Hydrol Process 15:909-26.

Ocampo CJ, Oldham CE, Sivapalan M. 2006. Nitrate attenuation in agricultural catchments: shifting balances between transport and reaction. Water Resour Res 42:W01408.

Onaindia M, de Manuel BF, Madariaga I, Rodríguez-Loinaz G. 2013. Co-benefits and trade-offs between biodiversity, carbon storage and water flow regulation. For Ecol Manag 289:1-9.

Oni SK, Tiwari T, Ledesma JLJ, Ågren AM, Teutschbein C, Schelker J, Laudon H, Futter MN. 2015. Local- and landscapescale impacts of clear-cuts and climate change on surface water dissolved organic carbon in boreal forests. J Geophys Res Biogeosci 120:2402-26.

Pellerin BA, Fernández IJ, Norton SA, Kahl JS. 2002. Soil aluminum distribution in the near-stream zone at the Bear Brook Watershed in Maine. Water Air Soil Pollut 134:189-204.

Peralta-Tapia A, Sponseller RA, Ågren A, Tetzlaff D, Soulsby C, Laudon H. 2015. Scale-dependent groundwater contributions influence patterns of winter baseflow stream chemistry in boreal catchments. J Geophys Res Biogeosci 120:847-58.

Petrone K, Buffam I, Laudon H. 2007. Hydrologic and biotic control of nitrogen export during snowmelt: a combined conservative and reactive tracer approach. Water Resour Res 43:W06420

Pinay G, Peiffer S, De Dreuzy JR, Krause S, Hannah DM, Fleckenstein JH, Sebilo M, Bishop K, Hubert-Moy L. 2015. Upscaling nitrogen removal capacity from local hotspots to low stream orders' drainage basins. Ecosystems 18:1101-20.

Ranalli AJ, Macalady DL. 2010. The importance of the riparian zone and in-stream processes in nitrate attenuation in undisturbed and agricultural watersheds-a review of the scientific literature. J Hydrol 389:406-15.

Rasilo T, Hutchins RHS, Ruiz-González C, del Giorgio PA. 2017. Transport and transformation of soil-derived $\mathrm{CO}_{2}, \mathrm{CH}_{4}$ and DOC sustain $\mathrm{CO}_{2}$ supersaturation in small boreal streams. Sci Total Environ 579:902-12.

Ravichandran M. 2004. Interactions between mercury and dissolved organic matter-a review. Chemosphere 55:319-31.

Raymond PA, Hartmann J, Lauerwald R, Sobek S, McDonald C, Hoover M, Butman D, Striegl R, Mayorga E, Humborg C, Kortelainen P, Dürr H, Meybeck M, Ciais P, Guth P. 2013. Global carbon dioxide emissions from inland waters. Nature 503:355-9.

Raymond PA, Saiers JE, Sobczak WV. 2016. Hydrological and biogeochemical controls on watershed dissolved organic matter transport: pulse-shunt concept. Ecology 97:5-16.

Richardson JS, Naiman RJ, Bisson PA. 2012. How did fixedwidth buffers become standard practice for protecting freshwaters and their riparian areas from forest harvest practices? Freshw Sci 31:232-8.

Riedel T, Zak D, Biester H, Dittmar T. 2013. Iron traps terrestrially derived dissolved organic matter at redox interfaces. Proc Natl Acad Sci USA 110:10101-5.

Rodhe A. 1989. On the generation of stream runoff in till soils. Nord Hydrol 20:1-8.
Ross DS, Matschonat G, Skyllberg U. 2008. Cation exchange in forest soils: the need for a new perspective. Eur J Soil Sci 59:1141-59.

Sanderman J, Lohse KA, Baldock JA, Amundson R. 2009. Linking soils and streams: sources and chemistry of dissolved organic matter in a small coastal watershed. Water Resour Res 45:W03418.

Schelker J, Eklöf K, Bishop K, Laudon H. 2012. Effects of forestry operations on dissolved organic carbon concentrations and export in boreal first-order streams. J Geophys Res Biogeosci 117:G01011.

Schiff S, Aravena R, Mewhinney E, Elgood R, Warner B, Dillon P, Trumbore S. 1998. Precambrian shield wetlands: hydrologic control of the sources and export of dissolved organic matter. Clim Chang 40:167-88.

Schlesinger WH. 1997. Biogeochemistry: an analysis of global change. Cambridge: Academic Press.

Seibert J, Bishop K, Rodhe A, McDonnell JJ. 2003. Groundwater dynamics along a hillslope: a test of the steady state hypothesis. Water Resour Res 39:1014.

Seibert J, Grabs T, Köhler S, Laudon H, Winterdahl M, Bishop K. 2009. Linking soil- and stream-water chemistry based on a Riparian Flow-Concentration Integration Model. Hydrol Earth Syst Sci 13:2287-97.

Selim HM, Kingery WL. 2003. Geochemical and hydrological reactivity of heavy metals in soils. Boca Raton: CRC Press.

Simmons RC, Gold AJ, Groffman PM. 1992. Nitrate dynamics in riparian forests—groundwater studies. J Environ Qual 21:659-65.

Skyllberg U, Raulund-Rasmussen K, Borggaard OK. 2001. pH buffering in acidic soils developed under Picea abies and Quercus robur-effects of soil organic matter, adsorbed cations and soil solution ionic strength. Biogeochemistry 56:51-74.

Skyllberg U, Qian J, Frech W, Xia K, Bleam WF. 2003. Distribution of mercury, methyl mercury and organic sulphur species in soil, soil solution and stream of a boreal forest catchment. Biogeochemistry 64:53-76.

Skyllberg U, Bloom PR, Qian J, Lin CM, Bleam WF. 2006. Complexation of mercury(II) in soil organic matter: EXAFS evidence for linear two-coordination with reduced sulfur groups. Environ Sci Technol 40:4174-80.

Smart RP, Soulsby C, Cresser MS, Wade AJ, Townend J, Billett MF, Langan S. 2001. Riparian zone influence on stream water chemistry at different spatial scales: a GIS-based modelling approach, an example for the Dee, NE Scotland. Sci Total Environ 280:173-93.

Strohmeier S, Knorr KH, Reichert M, Frei S, Fleckenstein JH, Peiffer S, Matzner E. 2013. Concentrations and fluxes of dissolved organic carbon in runoff from a forested catchment: insights from high frequency measurements. Biogeosciences 10:905-16.

Struyf E, Conley DJ. 2009. Silica: an essential nutrient in wetland biogeochemistry. Front Ecol Environ 7:88-94.

Struyf E, Opdekamp W, Backx H, Jacobs S, Conley DJ, Meire P. 2009. Vegetation and proximity to the river control amorphous silica storage in a riparian wetland (Biebrza National Park, Poland). Biogeosciences 6:623-31.

Sun QQ, Shi K, Damerell P, Whitham C, Yu GH, Zou CL. 2013. Carbon dioxide and methane fluxes: seasonal dynamics from inland riparian ecosystems, northeast China. Sci Total Environ 465:48-55. 
Swanson FJ. 1981. Land-water interactions: the riparian zone. Stroudsburg: Hutchinson Ross.

Tabacchi E, Correll DL, Hauer R, Pinay G, Planty-Tabacchi AM, Wissmar RC. 1998. Development, maintenance and role of riparian vegetation in the river landscape. Freshw Biol 40:497-516.

Temnerud J, Hytteborn JK, Futter MN, Köhler SJ. 2014. Evaluating common drivers for color, iron and organic carbon in Swedish watercourses. Ambio 43:30-44.

Tukey HB. 1970. Leaching of substances from plants. Annu Rev Plant Physiol 21:305-24.

Vestin JLK, Norström SH, Bylund D, Lundström US. 2008. Soil solution and stream water chemistry in a forested catchment II: influence of organic matter. Geoderma 144:271-8.

Vidon PGF, Hill AR. 2004. Landscape controls on the hydrology of stream riparian zones. J Hydrol 292:210-28.

Vidon P, Allan C, Burns D, Duval TP, Gurwick N, Inamdar S, Lowrance R, Okay J, Scott D, Sebestyen S. 2010. Hot spots and hot moments in riparian zones: potential for improved water quality managementl. J Am Water Resour Assoc 46:278-98.

Vought LBM, Dahl J, Pedersen CL, Lacoursière JO. 1994. Nutrient retention in riparian ecotones. Ambio 23:342-8.

Wallin MB, Grabs T, Buffam I, Laudon H, Ågren A, Öquist MG, Bishop K. 2013. Evasion of $\mathrm{CO}_{2}$ from streams-the dominant component of the carbon export through the aquatic conduit in a boreal landscape. Glob Chang Biol 19:785-97.

Ward JV. 1989. The four-dimensional nature of lotic ecosystems. J N Am Benthol Soc 8:2-8.

Winterdahl M, Wallin MB, Karlsen RH, Laudon H, Öquist M, Lyon SW. 2016. Decoupling of carbon dioxide and dissolved organic carbon in boreal headwater streams. J Geophys Res Biogeosci 121:2630-51.

Zimmer MA, Bailey SW, McGuire KJ, Bullen TD. 2013. Fine scale variations of surface water chemistry in an ephemeral to perennial drainage network. Hydrol Process 27:3438-51. 